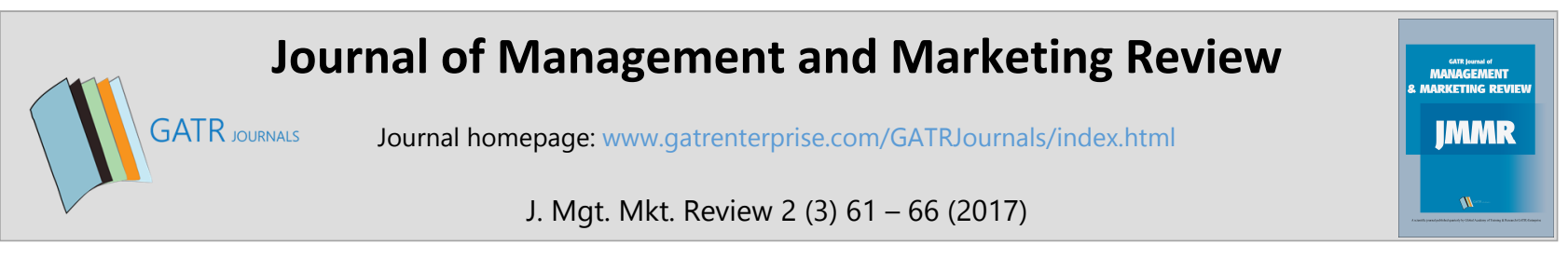

\title{
Green Practices in Northern Region Hotels of Malaysia
}

\author{
Noor Afza Amran ${ }^{1 *}$, Natrah Saad ${ }^{2}$ and Norhani Aripin ${ }^{3}$ \\ 1,2,3 Tunku Puteri Intan Safinaz School of Accountancy, Universiti Utara Malaysia, 06010 Sintok Kedah, Malaysia.
}

\begin{abstract}
Objective - The objective of this paper is to examine green practices of hotels located in Northern region of Malaysia. Methodology/Technique - The sample of the study is 115 hotels in Penang, Kedah and Perlis. Questionnaires were personally delivered to each respective hotel. The response rate for the survey is $43 \%$.

Findings - Findings from the survey indicate that hoteliers have started to show a positive sign towards adoption of green practices such as usage of power saving bulbs, water conservation, and recycling management program.

Novelty - The study urges more campaigns on awareness and the benefits of green practices. And, it will indirectly educate the hoteliers and society at large on the importance of saving the Mother Nature.
\end{abstract}

Type of Paper: Empirical.

Keywords: Green Practices; Environment; Recycle; Hotels; Malaysia.

JEL Classification: Q50, Q57.

\section{Introduction}

Environmental issues have become a major concern worldwide due to air and water pollution, and also waste disposal. These issues attract global community and industry attention, which lead to green awareness among people. The environmental issue in Malaysia has a long history which began with the river pollution from the development of tin mining operation. Years later, the rapid industrialization brought another environmental issue which is air pollution from the disposal of hazardous and communal waste. With regard to waste disposal, approximately there are 7.34 million tons of solid waste generated annually and local authorities spent up to $60 \%$ of their annual budget on waste management which costs the country between RM110 (USD33) and RM130 (USD39) to collect and dispose 1 ton of garbage (Ramayah, Lee, and Mohamad, 2010). In recent years, the environmental issues in Malaysia continue with deforestation, climate change and global warming. Intergovernmental Panel on Climate Change (IPCC) (2007) predicted that Malaysia's temperatures will increase by 0.6 to $4.5^{\circ} \mathrm{C}$ by year 2060 . In addition, the pollution index issued by Numbeo.com ranked Malaysia (with 64.73) at $74^{\text {th }}$ place out of 135 countries globally. Even though Malaysia is not regarded as amongst highly polluted country, yet the index is alarming and needs our serious attention. This research aims to provide information on the adoption of green practices amongst hotel operators in Northern region of Malaysia which is Kedah, Perlis and Penang. Northern region is selected because there are

\footnotetext{
* Paper Info: Received: January 9, 2017

Accepted: June 28, 2017

* Corresponding author:

E-mail: afza@uum.edu.my

Affiliation: Tunku Puteri Intan Safinaz School of Accountancy, Universiti Utara Malaysia, Malaysia.
} 
many islands and hotels which attract tourists to come and spent their holiday. More importantly, the findings could provide the basis for the government to propose the optimal practice of green practices in protecting the natural heritage. This paper is organized as follows. In section 2, the related literatures on green policy and green sustainability activities in hotel industry is discussed. In section 3 , the research methodology is presented. Section 4 discusses on the findings of the related hoteliers. Finally, section 5 highlights the conclusion of the paper.

\section{Literature Review}

\subsection{Green Hotel Policy}

The hotel industry has been pursuing green practices since the 1990s due to fluctuating economic levels and a strong focus on customer service (Claver-Cortes et al., 2007). The term "green hotels" describes hotels that strive to be more environmentally friendly through the efficient use of energy, water, and materials while providing high quality services. Green hotels conserve and preserve by saving water, reducing energy use, and reducing solid waste (Alexander \& Kennedy, 2002).

The hospitality industry will no longer be able to ignore its environmental responsibilities as it will have to respond to a number of pressures. Eco-hotel or environmental suitable hotel has to follow the basic principles of good housekeeping - based on maximizing benefits and minimizing costs. Those principles are at the same time the main principles of the ecology as a scientific approach and as a global movement aimed at preserving environment and implementing sustainable development concept (Alexander \& Kennedy, 2002). According to Rahman et al. (2012) competitiveness in terms of going green can improve profitability in the long run by lowering expenses and return the saving to the customers. Being green in nowadays marketplace adds value to the image of the hotels and resorts. Legitimation means complying with the environmental regulation provided by the government body in order to avoid being shut down or penalized in some way.

Another important reason is customers. According to Kirk (1998) most hoteliers would respond to the pressure from the society or customers. Hotel Melia manager claims that customers or visitors nowadays are more concern about the environment. They like to travel to eco-destination and choose a green hotel for their stay (Yusof \& Jamaludin, 2013). Accordingly, the failure to adopt environmental friendly practices may result in losing potential customers to other green operators (Butler, 2008). Above all, the main benefits of being green hoteliers are financial benefits. According to the report of the Department of Environment (DOE) UK, applying green approaches can reduce energy saving up to $20 \%$. Green hoteliers can gain profit by lowering the cost of energy, waste, water, emission cost, operational and maintenance cost (Butler, 2008). A Leadership in Energy and Environmental Design (LEED) certified building typically can save up to 30 to $50 \%$ in energy usage, $35 \%$ in carbon emissions, $40 \%$ in water consumption and $70 \%$ of solid waste (Peršić-Živadinov \& Blažević, 2010).

\subsection{Environmental Activities}

In upholding the green practices, hoteliers need to run environmental activities in their hotels. For hotels to achieve environmental objectives, it is important that all hotel employees participate. With their own proenvironmental behavior, they will encourage the environmental responsibility of their guests. In applying the green practices policy, hotels have started to save water, energy and waste. For example, the Fairmont Dallas Hotel, United States has installed tinted windows and digital thermostats in their guest rooms to reduce the consumption of energy resulting in $\$ 50,000$ savings in electricity costs annually (Graci \& Dodds, 2009). The Westin San Francisco Airport Hotel introduced a recycling program that promotes the recycling of 22 tons of materials and a savings of $\$ 6000$ annually. Whilst, $46 \%$ of a hotel's solid waste is food waste and since the food waste can be composted, hotels are increasingly recognizing that composting is a better alternative to dumping food waste, as composted waste can be used as organic fertilizers (Alexander \& Kennedy, 2002). In 
terms of water saving, The Fairmont Royal York in Toronto has saved 476,000 litres of water per day by having an installed water softener that reduces water use for laundry (Graci \& Dodds, 2009).

\section{Research Methodology}

A survey using questionnaires were distributed by hand to hotels in Northern region of Malaysia. The sample consists of 2 to 5 stars rating hotels that cover states of Kedah, Perlis and Penang because there are many beautiful island hotels located in this area. The total of 115 questionnaires based on the 2 and 5 stars rating hotels was personally delivered to Human Resource Manager of the hotels. He/she usually have to arrange and ensure that staffs get involved with the green practices applied in the hotels. Then after two weeks, the researchers collected the questionnaires from the respondents. The final sample collected was 50 questionnaires $(43 \%)$.

\section{Results and Discussion}

\subsection{Descriptive Statistics}

Table 1. Hotel Category

\begin{tabular}{|l|c|c|}
\hline Hotel category & Frequency & Percentage \\
\hline Resort & 44 & 38 \\
\hline Business & 44 & 38 \\
\hline Heritage & 9 & 8 \\
\hline Boutique & 18 & 16 \\
\hline Total & 115 & 100 \\
\hline
\end{tabular}

Table 1 illustrates the hotel category based on the sample collected. Based on Table 1, 44 hotels (38\%) are categorized as Resort hotels. Resort hotels are usually located in the mountains, on an island, or in some other remote locations, away from cities. These hotels have recreational facilities, such as golf, tennis, sailing, skiing and swimming pools. Resort hotels provide enjoyable and memorable guest experiences that encourage guest to repeat their staying at the resort. Next category is business hotels, which primarily cater for business travelers and usually located in downtown or business districts. Similar to resort hotel, business hotels represent 44 hotels (38\%) of the sample. Business hotels primarily serve business travelers, group tour, individual tourists and small conference groups. Guest amenities at business hotels may include complimentary newspapers, morning coffee, free local telephone calls, and breakfast. Further, there are $9(8 \%)$ heritage hotels included in the sample. Heritage hotels are hotels which are run in palaces, castles, forts, hunting loges and residence of any size built prior to 1950 . The facade, architectural features and general construction should have the distinctive qualities and ambience in keeping with the traditional way of life of the area. Finally, there are 18 (16\%) boutique hotels participated in this study. Boutique hotels are described as small stylish hotels, typically one situated in a fashionable urban location.

Table 2. Hotel Rating

\begin{tabular}{|l|c|c|}
\hline Hotel Rating & Frequency & Percentage \\
\hline 2-stars & 9 & 8 \\
\hline 3-stars & 44 & 38 \\
\hline 4-stars & 62 & 54 \\
\hline Total & 115 & 100 \\
\hline
\end{tabular}

Based on the respond of sample distributed to the hotels, rating for hotels is depicted in Table 2. Based on returned questionnaires, 62 hotels (54\%) represent 4 stars hotel. The 4 stars hotels are mostly large, formal 
hotels with smart reception areas, front desk service and bellhop service. The hotels are found near shopping, dining and other major attractions. The level of service is well above average and the rooms are well lit and well furnished. Restaurant dining is usually available and may include more than one choice. Some properties will offer continental breakfast or happy hour delicacies. Room service is usually available during most hours. Valet parking or garage service is also usually available. Concierge services, fitness centers and pools are often provided.

Based on the sample, 44 hotels $(38 \%)$ are 3 stars hotels. The 3 stars hotels offer more spacious accommodations that include well-appointed rooms and decorated lobbies. Bellhop service is usually not available. They are often located near major expressways or business areas, convenient to shopping and moderate to high priced attractions. The hotels usually feature medium-sized restaurants. Room service availability may vary. Valet parking, fitness centers and pools are also provided. There are 9 hotels (8\%) which are categorized as two stars hotels. These small hotels are managed by the proprietor. The hotels are two to four stories high and usually have a more personal atmosphere. It is mostly located near affordable attractions, major intersections and convenient to public transportation. Furnishings and facilities are clean but basic. Most of them will not have a restaurant on site, but are within walking distance to some good low-priced dining. Public access and pass for certain hours may be restricted.

\subsection{Green Practices}

Based on the survey in Table 3 below, 14\% of respondents claimed that they adopt green practices in their hotel, particularly in terms of energy-efficient lighting. In addition, $12 \%$ of hoteliers mentioned that they are supporting the local community towards the environmental awareness programs. About $10 \%$ of them are adopting the recycling management program. Further, about $6 \%$ hotel operators encourage their employees to suggest, identify, and spread green practices. Last but not least, $4 \%$ of hotels are controlling over air emissions to increase air quality. Overall, hoteliers are still undecided on the green practices based on the results of the survey. This reason may be due to high initial costs that need to be incurred for applying the green practices, or they may have limited budget for green practices.

Table 3. Green Practices

\begin{tabular}{|l|c|c|c|c|c|}
\hline \multirow{2}{*}{ Green Practices } & $\begin{array}{c}\text { Strongly } \\
\text { Disagree }\end{array}$ & Disagree & Neutral & \begin{tabular}{c} 
Agree \\
\cline { 2 - 5 }
\end{tabular} & $\begin{array}{c}\text { Strongly } \\
\text { Agree }\end{array}$ \\
\hline An upgrade to energy-efficient lighting in each of facilities. & 8 & $\mathbf{\%}$ & $\mathbf{\%}$ & $\mathbf{\%}$ & $\mathbf{\%}$ \\
\hline A control over air emissions to increase air quality. & 4 & 14 & 78 & 4 & 0 \\
\hline A formal recycling management program. & 4 & 30 & 56 & 10 & 0 \\
\hline $\begin{array}{l}\text { Support local community towards environmental } \\
\text { initiatives. }\end{array}$ & 2 & 24 & 62 & 12 & 0 \\
\hline $\begin{array}{l}\text { A program that encourages employees to suggest, identify, } \\
\text { and spread green practices. }\end{array}$ & 0 & 30 & 64 & 6 & 0 \\
\hline
\end{tabular}

\subsection{Environmental Activities}

Based on the result illustrates in Table 4, most hotel operators are still undecided on whether to adopt green practices or vice versa. Some hotels (8\%) have highly used dual flush toilets and toilet tanks with less than 9 liters of water. Next, $6 \%$ of the hotels have provided notice to encourage guests to conserve energy. There are $4 \%$ of hoteliers have installed extensive rain water collection system with filters that saved thousands of gallons of water, provided low flows sink aerators or water restrictor devices and created erosion control to protect the 
beach and save the trees. In sum, the trends towards adopting green practices are positive. The barriers may be due to high implementation costs, limited resources or experts on green aspects, the sense of awareness is still low among the operators and low support from the local governments.

Table 4. Environmental Activities

\begin{tabular}{|l|c|c|c|c|c|}
\hline Environmental Activities & $\begin{array}{c}\text { Highly } \\
\text { implement }\end{array}$ & $\begin{array}{c}\text { Partially } \\
\text { implement }\end{array}$ & Undecided & $\begin{array}{c}\text { Not really } \\
\text { implement }\end{array}$ & $\begin{array}{c}\text { Not } \\
\text { implement } \\
\text { at all }\end{array}$ \\
\cline { 2 - 6 } & $\%$ & $\%$ & $\%$ & \% & $\%$ \\
\hline $\begin{array}{l}\text { Provide dual flush toilets and toilet tanks with } \\
\text { less than 9 liters of water. }\end{array}$ & 8 & 14 & 64 & 14 & 0 \\
\hline $\begin{array}{l}\text { Provide notice to encourage guests to } \\
\text { conserve energy. }\end{array}$ & 6 & 32 & 54 & 8 & 0 \\
\hline $\begin{array}{l}\text { Provide low flows sink aerators or water } \\
\text { restrictor devices. }\end{array}$ & 4 & 14 & 78 & 4 & 0 \\
\hline $\begin{array}{l}\text { Create erosion control to protect the beach } \\
\text { and save the trees. }\end{array}$ & 4 & 14 & 62 & 20 & 0 \\
\hline $\begin{array}{l}\text { Install extensive rain water collection system } \\
\text { with filters that saved thousands of gallons of } \\
\text { water. }\end{array}$ & 4 & 30 & 56 & 10 & 0 \\
\hline Install solar panels for generating hot water. & 2 & 24 & 62 & 12 & 0 \\
\hline $\begin{array}{l}\text { Encourage guests to minimize water usage by } \\
\text { using notices. }\end{array}$ & 0 & 38 & 64 & 6 & 0 \\
\hline $\begin{array}{l}\text { Use key card system to cut off electricity } \\
\text { when guests are not in the room. }\end{array}$ & 0 & 38 & 46 & 16 & 0 \\
\hline Compost kitchen and garden wastes. & 0 & 22 & 66 & 12 & 0 \\
\hline Practice recycling and reusing. & 0 & 24 & 60 & 16 & 0 \\
\hline
\end{tabular}

\section{Conclusion}

This research found that the adoption of green practices is a positively taken by the hoteliers. There are hotels that have gradually implemented some green practices by reducing, reusing and recycling the wastes. However, most of hoteliers are not yet ready to fully implement the green practices and more campaigns should be highlighted in the future.

\section{References}

Alexander, S., \& Kennedy, C. (2002). Green hotels: Opportunities and resources for success. Zero Waste Alliance, 5(7), $1-9$.

Butler, J. (2008). The compelling "hard case" for "green" hotel development. Cornell Hospitality Quarterly, 49(3), 234244.

Claver-Cortés, E., Molina-Azorín, J. F., Pereira-Moliner, J., \& López-Gamero, M. D. (2007). Environmental strategies and their impact on hotel performance. Journal of Sustainable Tourism, 15(6), 663-679.

Graci, S., \& Dodds, R. (2008). Why go green? The business case for environmental commitment in the Canadian hotel industry. Anatolia, 19(2), 251-270.

Kirk, D. (1998). Attitudes to environmental management held by a group of hotel managers in Edinburgh. Journal of Hospitality Management, 17(1), 33-47. 
Peršić-Živadinov., \& Blažević. B. (2010). Conference Proceedings on Sustainable hotels: Sustainable life cycle practice in Croatian hotels. Tourism \& Hospitality Management, 161-177.

Rahman, I., Reynolds, D., \& Svaren, S. (2012). How "green” are North American hotels? An exploration of low-cost adoption practices. International Journal of Hospitality Management, 31(3), 720-727.

Ramayah, T., Lee, J. W. C., \& Mohamad, O. (2010). Green product purchase intention: Some insights from a developing country. Resources, Conservation and Recycling, 54(12), 1419-1427.

Yusof, Z. B., \& Jamaludin, M. (2013). Green approaches of Malaysian green hotels and resorts. Procedia-Social and Behavioral Sciences, 85, 421-431. 